\title{
Aspek Biologi Pari Kekeh (Rhynchobatus spp.) Studi Kasus di PPP Tasik Agung, Rembang
}

\author{
Ayu Safitri*, Sri Redjeki, Ita Widowati \\ Departemen IImu Kelautan, Fakultas Perikanan dan IImu Kelautan, Universitas Diponegoro \\ Jl. Prof. H. Soedarto S.H., Tembalang, Semarang, Jawa Tengah 50275 Indonesia \\ ${ }^{*}$ Corresponding author, e-mail : ayusafitri.yunanto@gmail.com
}

\begin{abstract}
ABSTRAK: Pari kekeh merupakan jenis pari dalam kelompok ordo Rhinopristiformes yang termasuk dalam salah satu komoditas perikanan penting di Indonesia. Pari kekeh telah dikategorikan sebagai spesies ikan terancam punah menurut IUCN dan termasuk ke dalam daftar Appendiks II CITES. Laut Jawa sebagai Wilayah Pengelolaan Perikanan 712 merupakan salah satu daerah penangkapan utama untuk komoditas pari kekeh. Tujuan penelitian ini untuk mengetahui komposisi jenis, hubungan panjang-berat, dan nisbah kelamin pari kekeh (Rhynchobatus spp.) yang didaratkan di PPP Tasik Agung, Rembang pada tanggal 7 September -6 Oktober 2020. Penelitian ini menggunakan metode deskriptif. Pengambilan data yang dilakukan berupa identifikasi jenis, pengukuran panjang total, panjang standar, berat, dan jenis kelamin ikan. Hasil penelitian menunjukkan terdapat tiga jenis ikan pari kekeh (Rhynchobatus spp.), yaitu Rhynchobatus australiae, Rhynchobatus springeri, dan Rhynchobatus laevis dengan komposisi secara berturut-turut sebanyak 49\%, 34\%, dan 17\%. Hubungan panjang total dan berat masing-masing jenis pari kekeh (Rhynchobatus spp.) menunjukkan pola pertumbuhan bersifat allometrik negatif $(b<3)$, yaitu pertumbuhan panjang ikan lebih cepat dari pertumbuhan berat. Nisbah kelamin ikan pari Rhynchobatus australiae sebesar 1:1,78, pari Rhynchobatus springeri sebesar 1:1,64, dan pari Rhynchobatus laevis sebesar 1:1,50. Hasil uji Chi-square $\left(\mathrm{X}^{2}\right)$ dari masing-masing jenis pari Rhynchobatus spp. menunjukkan bahwa perbandingan individu jantan dan betina berbeda nyata atau dapat dikatakan tidak seimbang.
\end{abstract}

Kata kunci: Pari Kekeh; Komposisi Jenis; Hubungan Panjang-Berat; Nisbah Kelamin

\section{The Biological Aspect of Wedgefishes (Rhynchobatus spp.) Case Study at PPP Tasik Agung, Rembang}

ABSTRACT: Wedgefishes are a type of ray in the order Rhinopristiformes, which is one of the important fisheries commodities in Indonesia. Wedgefishes have been categorized as an endangered species according to the IUCN and is included in the CITES Appendix II list. Java Sea as Fishery Management Area 712 is one of the main fishing areas for wedgefishes commodities. The aim of this study was to determine the species composition, length-weight relationship, and sex ratio of wedgefishes (Rhynchobatus spp.) landed at PPP Tasik Agung Rembang on September 7 - October 6, 2020. This study used a descriptive method. Data were collected by identifying the species, measuring the total length, standard length, weight and sex of the fish. The results showed that there were three types of wedgefishes (Rhynchobatus spp.) found in PPP Tasik Agung, namely Rhynchobatus australiae, Rhynchobatus springeri, and Rhynchobatus laevis with compositions of $49 \%, 34 \%$, and $17 \%$ respectively. The length-weight relationship of each type of wedgefishes (Rhynchobatus spp.) exhibited a negative allometric pattern of growth $(b<3)$, that is, fish length growth is faster than weight growth. The sex ratio of Rhynchobatus australiae was 1: 1.78, Rhynchobatus springeri were 1: 1.64, and Rhynchobatus laevis were 1: 1.50. The results of the Chi-square test $\left(X^{2}\right)$ of each type of Rhynchobatus spp. indicates that the ratio of male and female individuals is significantly different or can be said to be imbalance.

Keywords: Wedgefish; Species Composition; Length-Weight Relationship; Sex Ratio

\section{PENDAHULUAN}

Dent dan Clarke (2015) menyatakan bahwa Indonesia tercatat sebagai negara produsen dan penangkap hiu dan pari terbesar di dunia. Total produksi hiu dan pari di dunia pada tahun 2000 
hingga 2011 sekitar 13\%, diantaranya bersumber dari produksi hiu dan pari di Indonesia, yaitu sebesar 106.034 ton/tahun. Data dari Direktorat Jenderal Perikanan Tangkap (2018) menunjukkan bahwa jumlah produksi hiu dan pari di Indonesia pada tahun 2018 masing-masing adalah sebanyak 70.627 ton dan 130.932 ton, sedangkan di Laut Jawa menyumbang sekitar 37,02\% dari produksi tersebut yaitu 7.885 ton hiu dan 11.903 ton pari. Indonesia juga menjadi salah satu negara dengan tingkat ekspor hiu dan pari terbesar di dunia setelah China dan Thailand. Data dari Direktorat Konservasi dan Keanekaragaman Hayati Laut (2019) menunjukkan bahwa negara Dubai, Barcelona, Brazil, dan Rusia merupakan beberapa negara utama yang mengimpor hiu dan pari hidup dari Indonesia untuk komoditas akuaria. Kegiatan ekspor produk hiu dan pari Indonesia sejak tahun 2014 hingga 2019 setidaknya dilakukan ke 26 negara di seluruh benua dengan dominasi di Benua Asia. Menurut data Mutaqqin et al. (2018), bagian sirip memiliki tujuan utama pengiriman ke Hongkong, Singapura, dan Malaysia, bagian tulang dan kulit kering dikirim ke China, serta bagian daging dikirim ke Sri Lanka dan Singapura pada tahun 2018. Direktorat Jenderal Perikanan Tangkap (2016) menyebutkan bahwa produksi di Indonesia didominasi oleh produksi pari sebanyak $60 \%$, dimana pari kekeh termasuk didalamnya. Hal ini membutuhkan perhatian terhadap keberlangsungan sumber daya ikan pari kekeh di alam sebagai sumberdaya yang berkelanjutan.

Pari kekeh merupakan salah satu ikan dari kelas Chondrichthyans yang termasuk ke dalam kelompok ordo Rhinopristiformes. Kelompok ikan pari kekeh dan pari gitar (suku Rhynchobatidae dan Rhinobatidae) merupakan jenis pari berbentuk seperti ikan hiu (shark-like) yang komoditasnya tidak kalah penting dengan ikan hiu karena seluruh bagian tubuhnya dapat dimanfaatkan dan harga siripnya yang tinggi (Fahmi dan Dharmadi, 2013). Effendi et al. (2018) menyebutkan harga sirip per kilogram untuk ukuran terkecil $(12-20 \mathrm{~cm})$ sebesar 200 hingga 400 ribu rupiah dan ukuran lebih dari $40 \mathrm{~cm}$ mencapai 1,6 hingga 2 juta rupiah. Yuwandana et al. (2020a) menjelaskan bahwa pari kekeh sejak Agustus 2019 telah masuk kedalam Appendiks II CITES, sehingga perdagangan antar negara harus dikelola untuk menjamin pemanfaatannya sehingga terhindar dari ancaman terhadap kelestariannya. Pari kekeh juga telah dikategorikan sebagai spesies ikan terancam punah (Critically Endangered) menurut The International Union for Conservation of Nature (IUCN). Hal ini berdasarkan pada data populasinya yang terus menurun dan adanya kerusakan habitat di alam. Indikasi menurunnya populasi sumber daya ikan di suatu perairan dapat diketahui dari ukuran ikan dan hasil tangkapan yang menurun (Dharmadi dan Kasim, 2010). Berdasarkan data Direktorat Jendral Perikanan Tangkap (2017), produksi ikan pari nasional periode 2005 hingga 2017, khususnya pari kekeh, mengalami penurunan sebesar $80 \%$ dari 28.492 ton menjadi 7.483 ton.

Informasi perikanan pari kekeh (Rhynchobatus spp.) di Indonesia saat ini masih sangat terbatas, sehingga kajian mengenai perikanan pari kekeh sangat diperlukan sebagai salah satu dasar dalam pengelolaan pari kekeh. Laut Jawa (WPP712) merupakan salah satu daerah penangkapan utama untuk komoditas pari kekeh. Penelitian ini dilakukan di PPP Tasik Agung, Rembang yang terletak di Pantai Utara Jawa sebagai lokasi pendaratan hiu dan pari yang menjadi salah satu lokasi pendataan prioritas di Jawa Tengah. Lokasi ini tepat untuk melakukan penelitian mengenai komposisi jenis, sebaran ukuran, dan nisbah kelamin pari kekeh sebagai langkah awal dalam upaya pengelolaan dan konservasi sumberdaya pari kekeh (Rhynchobatus spp.) di Indonesia agar pari kekeh dapat menjadi sumberdaya yang berkelanjutan di alam.

\section{MATERI DAN METODE}

Materi penelitian berupa sampel Ikan pari kekeh (Rhynchobatus spp.) yang didaratkan di Pelabuhan Perikanan Pantai (PPP) Tasik Agung, Kab. Rembang, Jawa Tengah (Gambar 1). Pengambilan sampel dilakukan pada 7 September - 6 Oktober 2020 dengan total sampel sebanyak 257 individu. Dharmadi dan Kasim (2010) menjelaskan bahwa bulan Maret, Juni, dan September merupakan musim penangkapan pari di Laut Jawa. Pendatan pendaratan pari kekeh dilakukan setiap hari dengan aspek yang diteliti meliputi jenis spesies, panjang total, panjang standar, berat, dan jenis kelamin. Penelitian dilakukan dengan metode deskriptif, yaitu penelitian yang meneliti hubungan satu penelitian atau lebih tetapi tidak melakukan perbandingan dengan sampel penelitian yang berbeda dan tidak untuk membuat kesimpulan yang berlaku umum (Suryatati et al., 2019). Penentuan lokasi penelitian mengunakan purposive sampling method berdasarkan pada pertimbangan persebaran pari kekeh, yaitu di tempat pendaratan ikan pari kekeh dalam jumlah 
volume yang besar (Dharmadi et al., 2020). Pengambilan sampel menggunakan metode acak sederhana (simple random sampling) (Suryatati et al., 2019).

Panjang total (Total Length/TL) diukur mulai dari ujung depan moncong hingga ke ujung belakang ekor dalam posisi alami atau horizontal (Oktaviyani et al., 2020), sedangkan panjang standar (Standard Length/SL) diukur mulai dari ujung depan moncong hingga ke pangkal ekor. Panjang tubuh diukur menggunakan meteran dengan ketelitian $1 \mathrm{~mm}$. Pari kekeh kemudian ditimbang menggunakan timbangan digital dengan ketelitian $10 \mathrm{~g}$. Jenis kelamin ditentukan dari adanya organ kopulasi jantan (klasper) pada pari jantan, sedangkan betina tidak memiliki klasper (Oktaviyani et al., 2020). Nisbah kelamin didapatkan dari perbandingan antara jumlah ikan jantan dan jumlah ikan betina (Omar et al., 2015).

Persamaan nonlinear yang digunakan untuk memprediksi hubungan panjang berat adalah persamaan $\mathrm{W}=\mathrm{a} \cdot \mathrm{L}^{\mathrm{b}}$, parameter yang didapat dari persamaan tersebut dapat dihitung setelah diubah kedalam bentuk model regresi linear dengan transformasi-log pada variabel. Regresi linear digunakan untuk mengetahui hubungan dan seberapa besar pengaruh antara variabel bebas (X) dan variabel terikat (Y). Model logaritma natural digunakan untuk menyamakan perbedaan dalam satuan variabel, mendekatkan skala data, dan mengetahui koefisien yang menunjukkan elastisitas. Persamaan dengan menerapkan logaritma natural, sehingga dapat memprediksi logaritma berat sebagai fungsi dari logaritma panjang untuk mengestimasi pola pertumbuhannya.

Analisis deskriptif dilakukan untuk menggambarkan komposisi jenis, hubungan panjang total dan berat, distribusi frekuensi panjang dan berat, dan nisbah kelamin (Omar et al., 2015). Identifikasi spesies pari kekeh dilakukan dengan mengacu pada buku panduan identifikasi Wedgefishes and Giant Guitarfishes: A Guide to Species Identification oleh Jabado (2019). Analisis data ukuran panjang dan berat dikelompokkan ke dalam kelas-kelas menggunakan metode interval kelas teratur. Frekuensi selang kelas ikan ditentukan dengan rumus distribusi frekuensi dan jumlah kelas ditentukan dengan rumus Sturguess (Rizal dan Jaliadi, 2018). Analisis hubungan panjang-berat pari kekeh menggunakan persamaan kuadrat yang dilinierkan dengan transformasi logaritma (Rizal dan Jaliadi, 2018). Analisis nisbah kelamin ditentukan dengan menggunakan uji Chi-square $\left(\mathrm{X}^{2}\right)$ yang berfungsi untuk mengetahui keseimbangan perbandingan populasi antara ikan jantan dan betina (Omar et al., 2015).

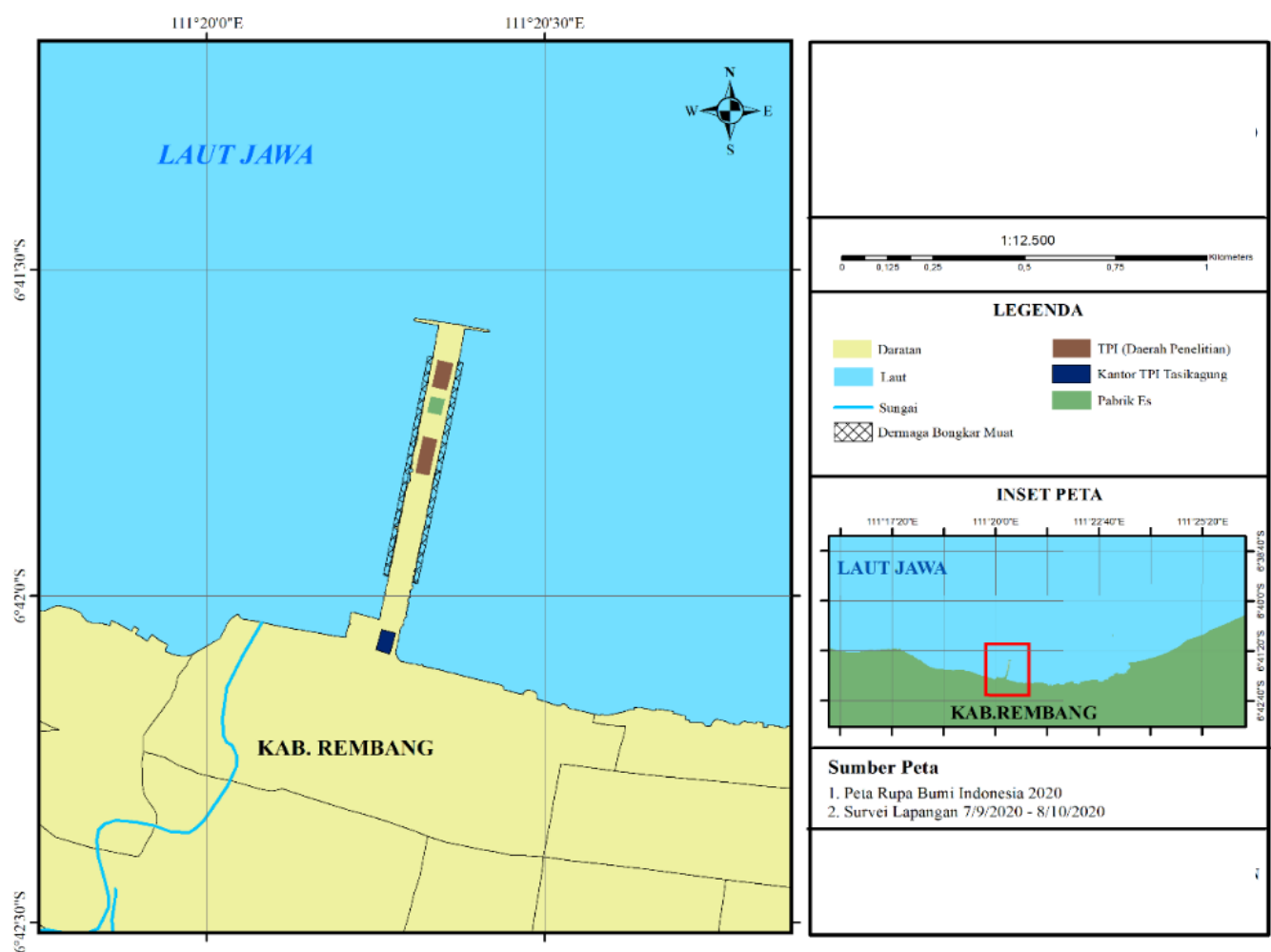

Gambar 1. Peta Lokasi Penelitian di PPP Tasik Agung, Rembang 


\section{HASIL DAN PEMBAHASAN}

Data produksi ikan pari di Kabupaten Rembang selama periode tahun 2014-2018 berdasarkan data tahunan Dinas Kelautan dan Perikanan Kabupaten Rembang menunjukkan total produksi seluruh jenis ikan di Kabupaten Rembang tahun 2014 sebanyak $60.772 .646 \mathrm{~kg}$ dengan nilai produksi $\mathrm{Rp}$ 396.226.466.555,00, dimana sebanyak $1.423 .491 \mathrm{~kg}$ nya merupakan produksi pari dengan nilai produksi Rp 4.587.763.150,00 (DKP Kab. Rembang, 2016). Nilai produksi ikan total dan ikan pari di Kabupaten Rembang terus mengalami penurunan pada tahun 2014-2017, dimana total produksi ikan pada tahun 2017 hanya mencapai $36.243 .036 \mathrm{~kg}$ dengan nilai produksi $\mathrm{Rp} 410.814 .488 .000,00$, dan sebanyak $699.656 \mathrm{~kg}$ nya merupakan produksi pari dengan nilai produksi $\mathrm{Rp} 4.311 .259 .200,00$. Nilai produksi pada 2018 mengalami peningkatan, dimana total produksi sebanyak $42.452 .505 \mathrm{~kg}$ dengan nilai produksi $\mathrm{Rp} 405.253 .792 .000,00$, dengan $754.330 \mathrm{~kg}$ nya merupakan produksi pari dengan nilai produksi Rp 4.631.602.000,00 (DKP Kab. Rembang, 2018; Azidha et al., 2021).

Hasil pendataan pendaratan ikan pari kekeh (Rhynchobatus spp.) di PPP Tasik Agung tercatat sebanyak 257 individu dari 3 (tiga) spesies, diantaranya adalah Rhynchobatus australiae, Rhynchobatus springeri, dan Rhynchobatus laevis. Hal ini sesuai dengan Compagno dan Last (2010) yang menyatakan bahwa spesies Rhynchobatus australiae dan Rhynchobatus springeri dapat ditemukan di wilayah Indonesia, dan Simeon et al. (2019) yang menyatakan spesies Rhynchobatus laevis dapat ditemukan di wilayah Indonesia. Genus Rhynchobatus diketahui memiliki keseluruhan sebanyak 8 spesies di dunia (Jabado, 2019). Identifikasi spesies yang dilakukan menunjukkan individu pari Rhynchobatus australiae memiliki ciri morfologi berupa 3 titik putih sejajar di atas dan 2 titik putih di bawah tanda hitam di dada, dan permukaan punggung yang hampir seragam kehitaman tanpa tanda pada beberapa individu dewasa. Individu pari Rhynchobatus springeri ditunjukkan dari adanya tanda gelap yang biasanya di belakang mata, tanda hitam di dada yang dikelilingi oleh 3-4 bintik putih, dan terdapat 3-4 baris bintik putih di setiap sisi tubuh yang memanjang di sepanjang ekor. Individu pari Rhynchobatus laevis memiliki ciri berupa tanda hitam di dada yang sering berbentuk garis melingkar, dikelilingi oleh 4-7 bintik putih, dan memiliki 4-5 baris bintik putih di setiap sisi tubuh di bawah sirip punggung pertama (Gambar 2).

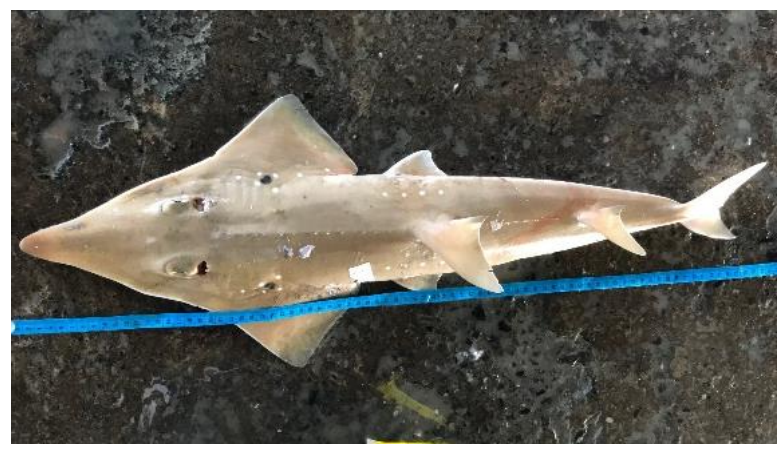

Rhynchobatus australiae

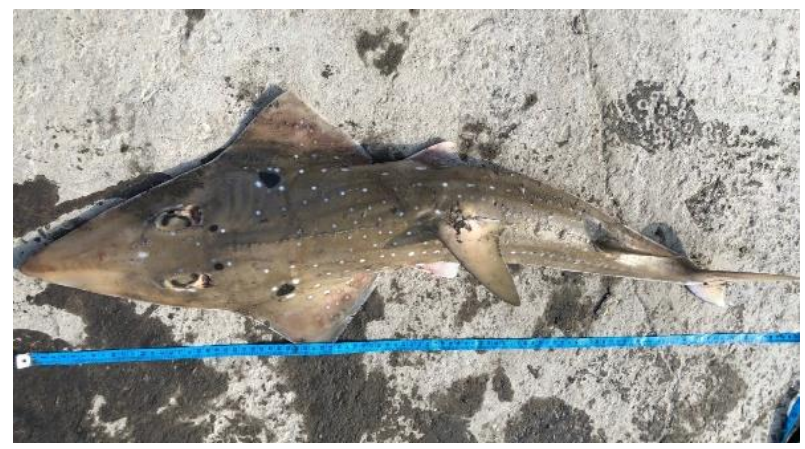

Rhynchobatus springeri

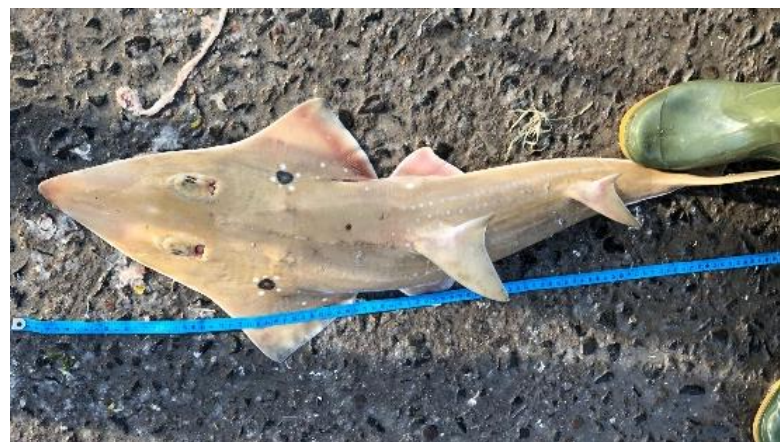

Rhynchobatus laevis

Gambar 2. Jenis ikan pari di PPP Tasik Agung 
Komposisi jenis ikan pari kekeh yang didaratkan di PPP Tasik Agung terbesar adalah jenis Rhynchobatus australiae sebanyak 125 individu dengan komposisi mencapai 49\% dari keseluruhan jenis ikan pari kekeh yang tercatat, diikuti oleh jenis Rhynchobatus springeri sebanyak 87 individu dengan komposisi mencapai 34\%. Komposisi terendah adalah jenis Rhynchobatus laevis sebanyak 45 individu dengan komposisi 17\% (Gambar 3). Spesies Rhynchobatus australiae sebelumnya dianggap sebagai Rhynchobatus djiddensis. Spesies Rhynchobatus djiddensis diketahui memiliki persebaran terbatas di Laut Merah, Teluk Persia, dan Samudra Hindia bagian barat (Last et al., 2016), tetapi sebelumnya spesies ini dianggap memiliki persebaran yang lebih luas karena kesulitan dalam identifikasi atau kebingungan dalam membedakan spesies ini dengan kerabatnya (Kyne et al., 2019). Spesies Rhynchobatus australiae sebelumnya juga sulit dibedakan dengan Rhynchobatus laevis (Smoothnose Wedgefish) karena kemiripan morfologi yang membuat klasifikasi spesies lebih sulit (Zain et al., 2018). Spesies Rhynchobatus laevis mulai banyak tercatat di perairan Indonesia sejak tahun 2019, seperti diantaranya di PPP Tegalsari Tegal, PPP Tasik Agung Rembang, dan PPP Bajomulyo Pati (Yuwandana et al., 2020b).

Jenis pari Rhynchobatus australiae diketahui persebarannya banyak ditemukan di perairan yang berhubungan dengan Samudera Hindia, yaitu di perairan New South Wales, Australia dan ditemukan endemik di Perairan Thailand, Madagascar, Indonesia Timur, Jawa, Bali dan Lombok (Alaydrus et al., 2014). Spesies dari genus Rhynchobatus di Pasifik Barat diantaranya termasuk Rhynchobatus australiae yang terdapat di Asia Tenggara dan Australia, mulai dari Thailand, Taiwan dan Indonesia hingga sub-tropis Australia; Rhynchobatus springeri di Asia Tenggara; dan terakhir spesies Rhynchobatus laevis yang diketahui terdapat di Zanzibar, Laut Arab, Oman, Teluk Persia, India, Sri Lanka, Bangladesh (Giles et al., 2016) dan Indonesia (Simeon et al., 2019).

Perhitungan persamaan hubungan panjang total dan berat pada ikan pari kekeh (Rhynchobatus spp.) selama penelitian dapat dimanfaatkan untuk menjelaskan sifat pertumbuhan dari ikan tersebut (Triharyuni et al., 2017).

Hasil perhitungan regresi antara hubungan panjang total dan berat ikan Rhynchobatus spp. yang didata di PPP Tasik Agung menunjukkan nilai yang bervariasi pada tiap spesies. Perhitungan regresi pada spesies Rhynchobatus australiae terhadap 125 individu, yaitu $Y=2,2898 x-8,2588$. Nilai eksponen b sebesar 2,2898 dan nilai a sebesar $(-8,2588)$. Nilai konstanta determinasi sebesar $87,6 \%$. Perhitungan regresi pada spesies Rhynchobatus springeri terhadap 87 individu, yaitu $\mathrm{Y}=2,7059 \mathrm{x}-10,272$. Nilai eksponen b sebesar 2,7059 dan nilai a sebesar $(-10,272)$. Nilai konstanta determinasi sebesar $91,8 \%$. Perhitungan regresi pada spesies Rhynchobatus laevis terhadap 45 individu, yaitu $Y=2,7348 x-10,373$. Nilai eksponen b sebesar 2,7348 dan nilai a sebesar $(-10,373)$. Nilai konstanta determinasi sebesar $94,1 \%$. Sifat atau pola pertumbuhan dari ketiga jenis sampel ikan pari menunjukkan nilai $b$ kurang dari $3 \quad(b<3)$, dimana menunjukkan bahwa pola pertumbuhannya adalah allometrik negatif, yaitu pertambahan panjang yang lebih dominan atau lebih cepat dari pertambahan berat (Gambar 4). Nilai dari konstanta determinasi dapat menunjukkan ukuran goodness-of-fitmodel regresi. Nilai konstanta determinasi dari seluruh spesies ikan pari yang diteliti memiliki nilai yang tinggi, yaitu 87,6-94,1\%. Triharyuni et al. (2017) menyatakan bahwa nilai konstanta determinasi yang semakin besar mendekati 1 memiliki arti bahwa variabel - variabel independen memiliki kemampuan memberikan semua informasi yang dibutuhkan untuk memprediksi variabel dependen (Ghozali, 2016).

Hasil allometrik negatif juga didapat dalam penelitian pada ikan pari Rhynchobatus spp. di PPN Brondong, Lamongan (Azidha et al., 2021) dan pada ikan pari Neotrygon kuhlii di perairan Selat Sunda (Abubakar et al., 2015). Pola pertumbuhan ikan pari Rhynchobatus spp. di PPP Tasik Agung memiliki hasil yang berbeda apabila dibandingkan dengan penelitian ikan pari Himantura walga di Cilincing, Jakarta Utara yang memiliki pola pertumbuhan alometrik positif (Novariani et al., 2014). Perbedaan pola pertumbuhan pada spesies yang berbeda atau lokasi yang berbeda adalah hal yang mungkin terjadi. Abubakar et al. (2015) menyebutkan bahwa perbedaan pola ini dapat dipengaruhi oleh beberapa faktor, diantaranya perbedaan laju pertumbuhan, perbedaan umur, tahap perkembangan gonad, serta faktor dari ketersediaan makanan dan kondisi dari tiap perairan yang berbeda. 


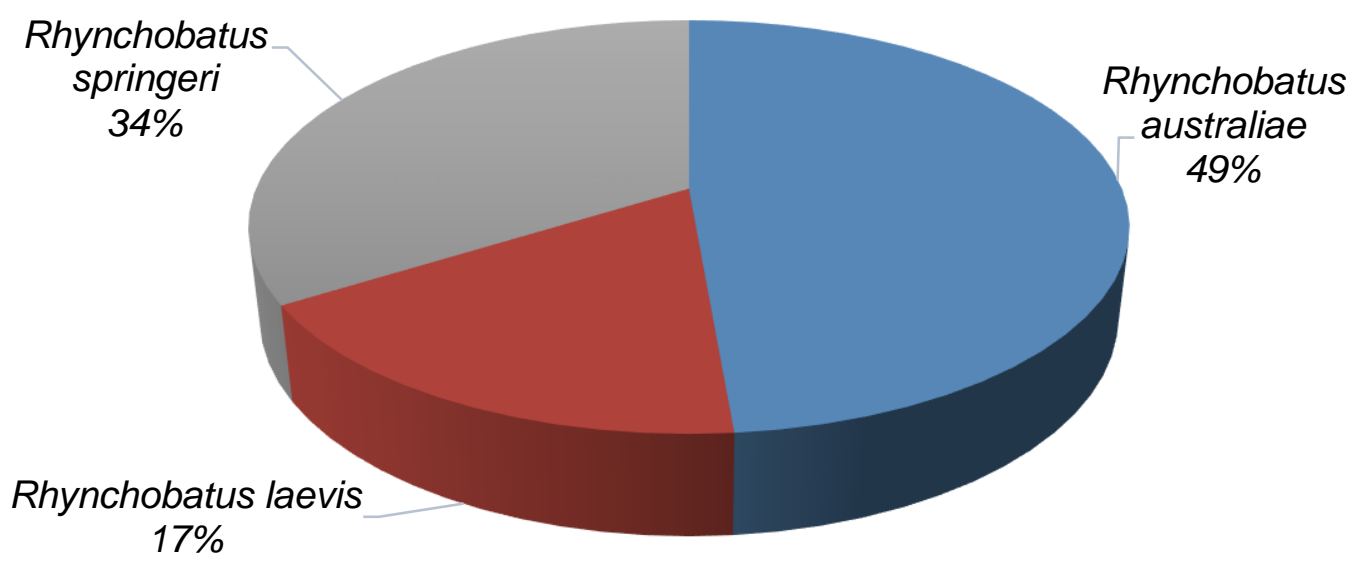

Gambar 3. Komposisi Jenis Rhynchobatus spp. di PPP Tasik Agung

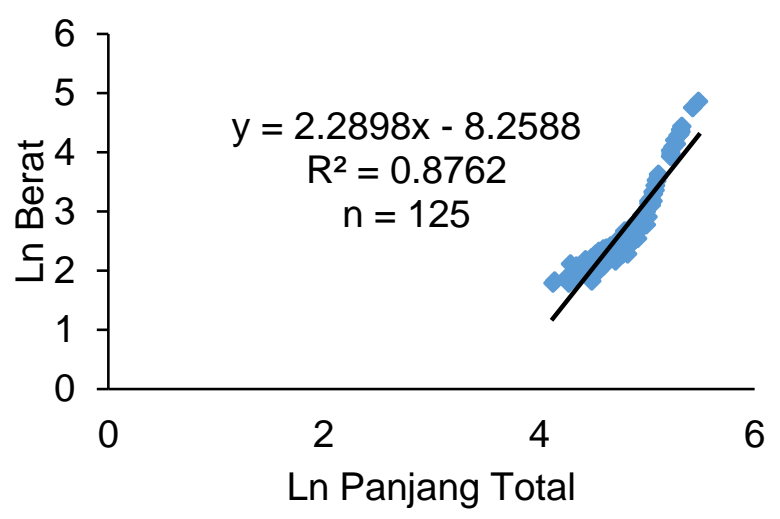

Rhynchobatus australiae

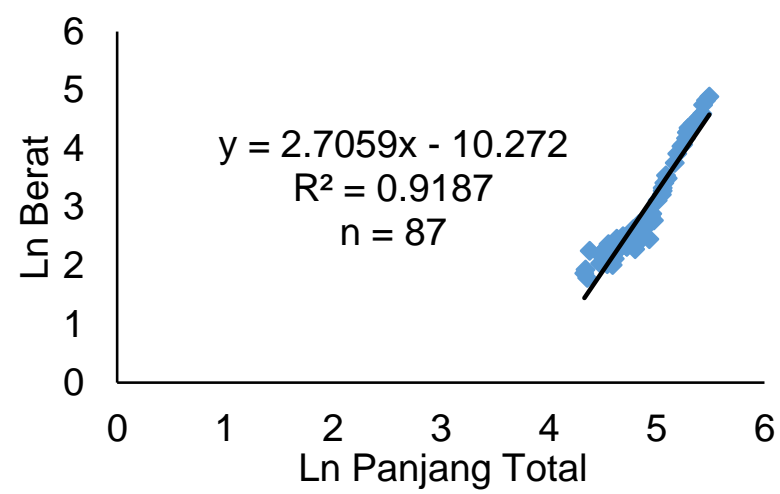

Rhynchobatus springeri

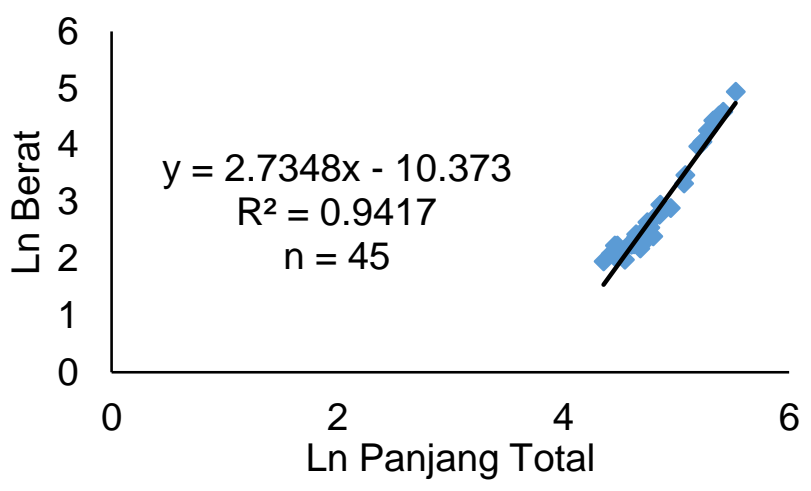

Rhynchobatus laevis

Gambar 4. Hubungan Panjang Total dan Berat di PPP Tasik Agung

Hasil dari pendataan Ikan pari kekeh (Rhynchobatus spp.) yang didaratkan di PPP Tasik Agung sebanyak 257 individu terbagi kedalam kisaran panjang yang berbeda-beda. Jenis pari Rhynchobatus australiae memiliki kisaran panjang total betina $63-240 \mathrm{~cm}$ dan jantan $62-227 \mathrm{~cm}$, Rhynchobatus springeri memiliki kisaran panjang total betina $76-242 \mathrm{~cm}$ dan jantan $80-220 \mathrm{~cm}$, dan Rhynchobatus laevis memiliki kisaran panjang total betina $78-251 \mathrm{~cm}$ dan jantan $83-206 \mathrm{~cm}$. Distribusi panjang terbanyak dari jenis Rhynchobatus australiae yaitu pada kisaran panjang 85-107 cm, Rhynchobatus springeri yaitu pada kisaran panjang $97-117 \mathrm{~cm}$, dan Rhynchobatus laevis yaitu 
pada kisaran panjang 103-127 cm, dimana frekuensi panjang tersebut terletak pada kelas panjang kedua dari masing-masing spesies (Gambar 5). Distribusi panjang terbanyak dari ketiga jenis ikan pari kekeh termasuk dalam ukuran ikan muda (immature).

Spesies Rhynchobatus australiae jantan diketahui dapat mencapai umur 14 tahun dan betina mencapai umur 12 tahun (Simeon et al., 2019). White et al. (2006) menjelaskan bahwa pari Rhynchobatus australiae berukuran $46-50 \mathrm{~cm}$ pada saat lahir dan dapat memiliki panjang tubuh mencapai $300 \mathrm{~cm}$. Yuwandana et al. (2020a) menyebutkan bahwa Rhynchobatus australiae mencapai Lm (rata-rata panjang pertama matang kelamin) pada ukuran $212,77 \mathrm{~cm}$ untuk jantan dan $215,62 \mathrm{~cm}$ untuk betina, dengan panjang tubuh mencapai $296 \mathrm{~cm}$ untuk jantan dan $300 \mathrm{~cm}$ untuk betina. Rhynchobatus springeri mencapai Lm pada ukuran $96,73 \mathrm{~cm}$ untuk jantan dan $184,22 \mathrm{~cm}$ untuk betina, dengan panjang tubuh mencapai $246 \mathrm{~cm}$ untuk jantan dan $285 \mathrm{~cm}$ untuk betina. Rhynchobatus laevis mencapai Lm pada ukuran $185,65 \mathrm{~cm}$ untuk jantan dan 219,19 cm untuk betina, dengan panjang tubuh mencapai $258 \mathrm{~cm}$ untuk jantan dan $305 \mathrm{~cm}$ untuk betina.

Hasil penelitian di PPP Tasik Agung berdasarkan distibusi ukuran panjang menunjukkan bahwa pada pari Rhynchobatus australiae, sebanyak $97,8 \%$ individu jantan dan $98,8 \%$ individu betina tertangkap pada kondisi belum dewasa dan belum mengalami minimal satu kali pemijahan, sedangkan Rhynchobatus springeri sebanyak $93,9 \%$ individu jantan dan $74,1 \%$ individu betina, serta Rhynchobatus laevis sebanyak $88,9 \%$ individu jantan dan $92,6 \%$ individu betina. Hasil ini menunjukkan bahwa ketiga jenis pari Rhynchobatus spp. memiliki hasil melebihi $50 \%$ untuk hasil tangkapan individu muda (immature). Yuwandana et al. (2020a) menjelaskan kondisi penangkapan pari kekeh yang didominasi oleh ikan ukuran kecil melebihi $50 \%$ memiliki resiko tinggi terhadap overfishing. Ben-Hasan et al. (2021) menjelaskan keadaan seperti ini dapat menimbulkan kondisi growth over fishing, yaitu tingginya tingkat penangkapan ikan muda sebelum mencapai pertumbuhan optimum sehingga menimbulkan potensi terjadinya pengurangan jumlah ikan dewasa.

Habitat yang disenangi ikan pari ini adalah dasar perairan pantai yang dangkal dengan substrat pasir dan lumpur, dekat rataan terumbu karang (reef flat), laguna, teluk, dan muara sungai (Simeon et al., 2019). Pari kekeh Rhynchobatus australiae diketahui hidup pada kedalaman 0-60 meter (Kyne et al., 2019), Rhynchobatus springeri pada kedalaman 16-40 meter (Kyne, 2019), dan Rhynchobatus laevis pada kedalaman 0-60 meter (Kyne dan Jabado, 2019). Menurut Kusrini dan Aba (2019), umumnya spesies ini mendiami daerah dasar perairan, namun juvenilnya banyak ditemukan di sekitar perairan pantai hutan bakau dan pulau karang. Sedangkan pari dewasa banyak ditemukan di daerah lepas pantai yang lebih dalam. Hal ini dapat menjelaskan kondisi penangkapan pari kekeh yang didominasi oleh ikan ukuran kecil dalam penelitian, dimana daerah penangkapan nelayan PPP Tasik Agung menggunakan cantrang maupun rawai dasar (bottom longline) menurut Yuwandana et al. (2020b) terletak sekitar kepulauan Masalembu, dengan ciri lingkungan mempunyai struktur biodiversitas habitat yang tinggi, seperti terumbu karang, hutan bakau, dan rumput laut, sehingga sangat sesuai dengan daerah hidup juvenil dari pari kekeh. Faktor lain dari kondisi penangkapan ini salah satunya dijelaskan oleh Faizah dan Chodrijah (2020) bahwa pola rekrutmen dari pari Rhynchobatus australiae memiliki dua puncak, dimana puncak minor terjadi pada bulan Maret dan puncak mayor terjadi pada bulan Agustus.

Ikan pari kekeh Rhynchobatus spp. yang didaratkan di PPP Tasik Agung sebanyak 257 individu tercatat terbagi ke dalam beberapa kisaran berat. Jenis pari Rhynchobatus australiae memiliki kisaran berat betina 6,2-129 kg dan jantan 6-116,3 kg. Jenis pari Rhynchobatus springeri memiliki kisaran berat betina $6-133 \mathrm{~kg}$ dan jantan 7,5-92,4 kg. Jenis pari Rhynchobatus laevis memiliki kisaran berat betina 7-139 kg dan jantan 7,2-84 kg. Distribusi berat terbanyak dari jenis Rhynchobatus australiae dan Rhynchobatus springeri yaitu pada kisaran berat 5,5-21,5 kg, sedangkan jenis Rhynchobatus laevis pada kisaran berat 6,5-25,5 kg. Frekuensi berat terbesar terletak pada kelas pertama (lebih dari 70\%) (Gambar 6).

Hasil pengamatan terhadap pari kekeh yang diperoleh selama penelitian menunjukkan jumlah individu betina lebih banyak dibanding individu jantan, dimana dari 257 individu sampel diantaranya terdiri atas 96 individu jantan (37\%) dan 161 individu betina (63\%) (Gambar 7). Persentase jenis kelamin jantan dan betina berturut-turut adalah Rhynchobatus australiae sebesar $36 \%$ dan $64 \%$, Rhynchobatus springeri sebesar $38 \%$ dan $62 \%$, serta Rhynchobatus laevis sebesar $40 \%$ dan $60 \%$ (Gambar 8). Nilai nisbah kelamin dari Rhynchobatus australiae yaitu 1:1,78. Hasil uji Chi-square $\left(\mathrm{X}^{2}\right)$ diperoleh nilai 9,8 dengan nilai $\mathrm{X}^{2}$ tabel 3,1. Nilai nisbah kelamin dari Rhynchobatus 
Tabel 1. Uji Chi-square Nisbah Kelamin Ikan Pari Kekeh (Rhynchobatus spp.) Jantan dan Betina yang diperoleh Selama Penelitian

\begin{tabular}{cccccccc}
\hline \multirow{2}{*}{ Kode } & \multicolumn{2}{c}{ Jumlah (ekor) } & \multicolumn{2}{c}{ Nisbah kelamin } & \multirow{2}{*}{$\mathrm{X}^{2}$ hitung } & \multirow{2}{*}{$\mathrm{X}^{2}$ Tabel } & Keterangan \\
\cline { 2 - 5 } & Jantan & Betina & Jantan & Betina & & & \\
\hline RA & 45 & 80 & 1 & 1,78 & 9,8 & 3,1 & Berbeda Nyata \\
RS & 33 & 54 & 1 & 1,64 & 5,06897 & 2,15 & Berbeda Nyata \\
RL & 18 & 27 & 1 & 1,50 & 1,8 & 1,1 & Berbeda Nyata \\
\hline
\end{tabular}

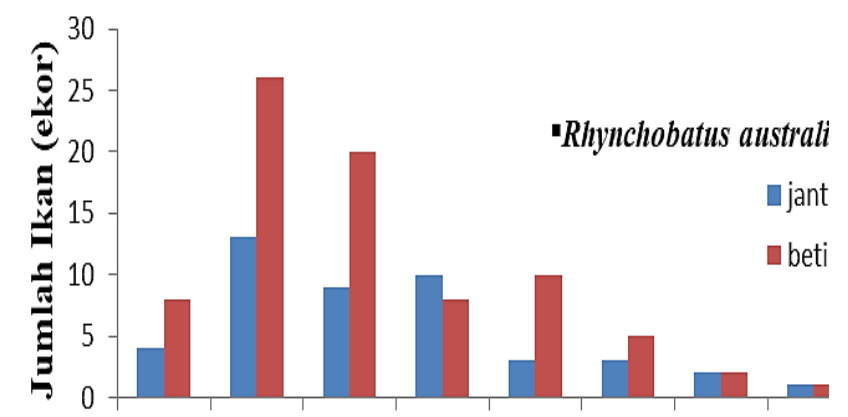

62-84 85-107 108-130 131-153 154-176177-199 200-222 223-2

Kisaran Panjang Total (cm)

Rhynchobatus australiae

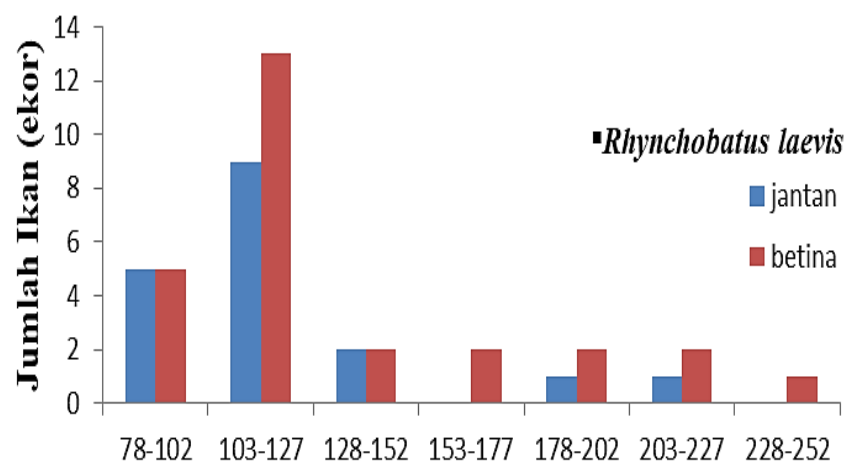

Kisaran Panjang Total (cm)

Rhynchobatus laevis

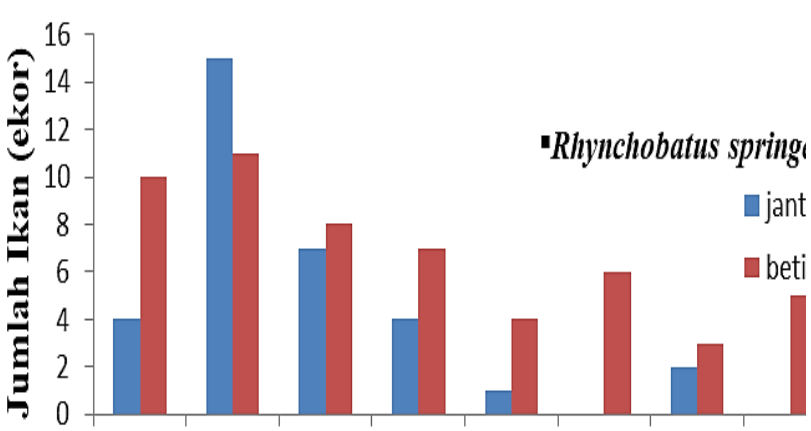

76-96 97-117 118-138 139-159 160-180 181-201 202-222 223-2 Kisaran Panjang Total (cm) Rhynchobatus springeri

Gambar 5. Distribusi Frekuensi Panjang Total Ikan Pari Kekeh di PPP Tasik Agung

springeri yaitu 1:1,64. Hasil uji Chi-square $\left(X^{2}\right)$ diperoleh nilai 5,07 dengan nilai $X^{2}$ tabel 2,15. Nilai nisbah kelamin dari Rhynchobatus laevis yaitu 1:1,50. Hasil uji Chi-square $\left(X^{2}\right)$ diperoleh nilai 1,8 dengan nilai $X^{2}$ tabel 1,1 . Hasil uji Chi-square $\left(X^{2}\right)$ menunjukkan bahwa perbandingan individu jantan dan betina pada seluruh jenis ikan pari Rhynchobatus spp. berbeda nyata (Tabel 1).

Keseimbangan perbandingan jumlah jantan dan betina dalam suatu populasi akan menentukan keberhasilan proses rekruitmen suatu spesies ikan. Hasil uji Chi-square yang berbeda nyata dapat menunjukkan bahwa peluang individu untuk melakukan reproduksi akan berkurang karena antar individu akan saling berkompetisi untuk mendapatkan pasangan, maka dapat menjadi hambatan untuk mempertahankan kelestarian diluar adanya kematian alami dan kegiatan penangkapan. Salah satu faktor penyebab timbulnya variasi nisbah kelamin adalah ketersediaan ikan dan selektivitas alat tangkap. Omar et al. (2015) menyebutkan bahwa faktor-faktor seperti kondisi lingkungan, penyebaran individu jantan dan betina yang tidak merata, serta faktor penangkapan, seperti wilayah penangkapan dan alat tangkap dapat menimbulkan variasi nisbah kelamin di alam. 


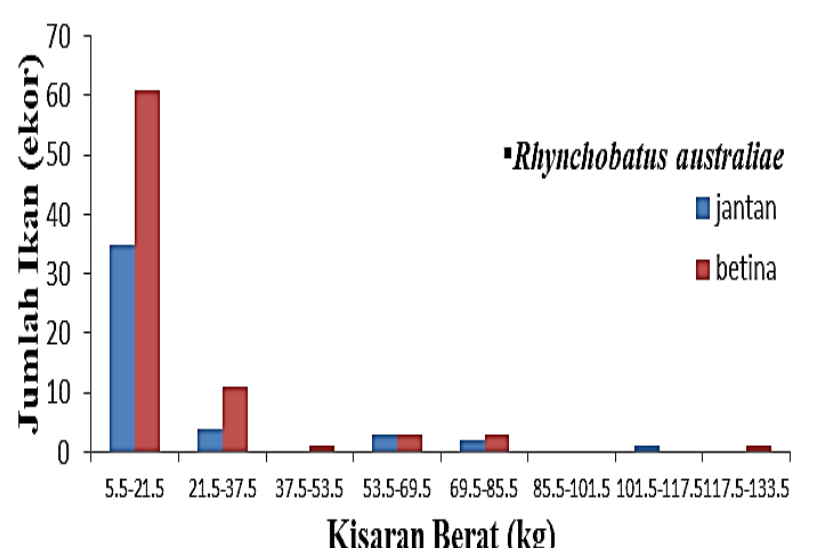

Rhynchobatus australiae

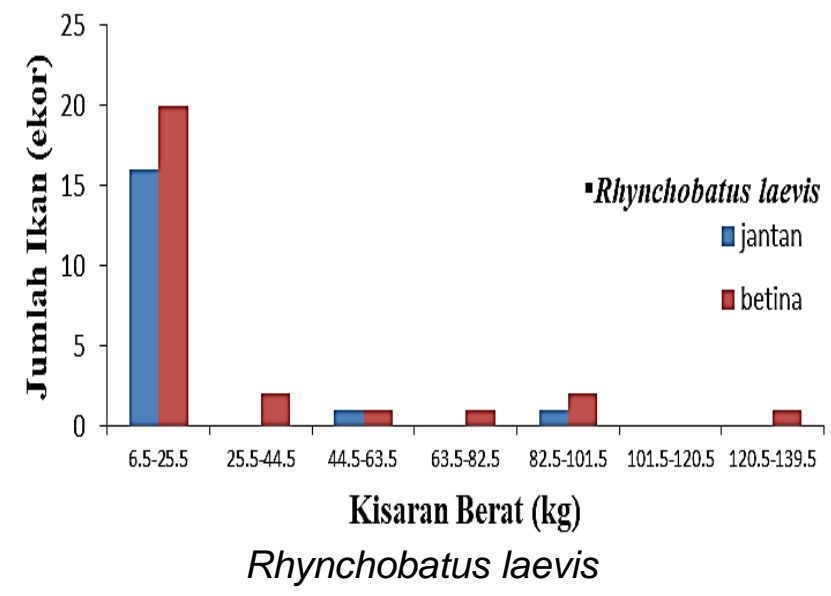

Gambar 6. Distribusi Frekuensi Berat Ikan Pari Kekeh di PPP Tasik Agung

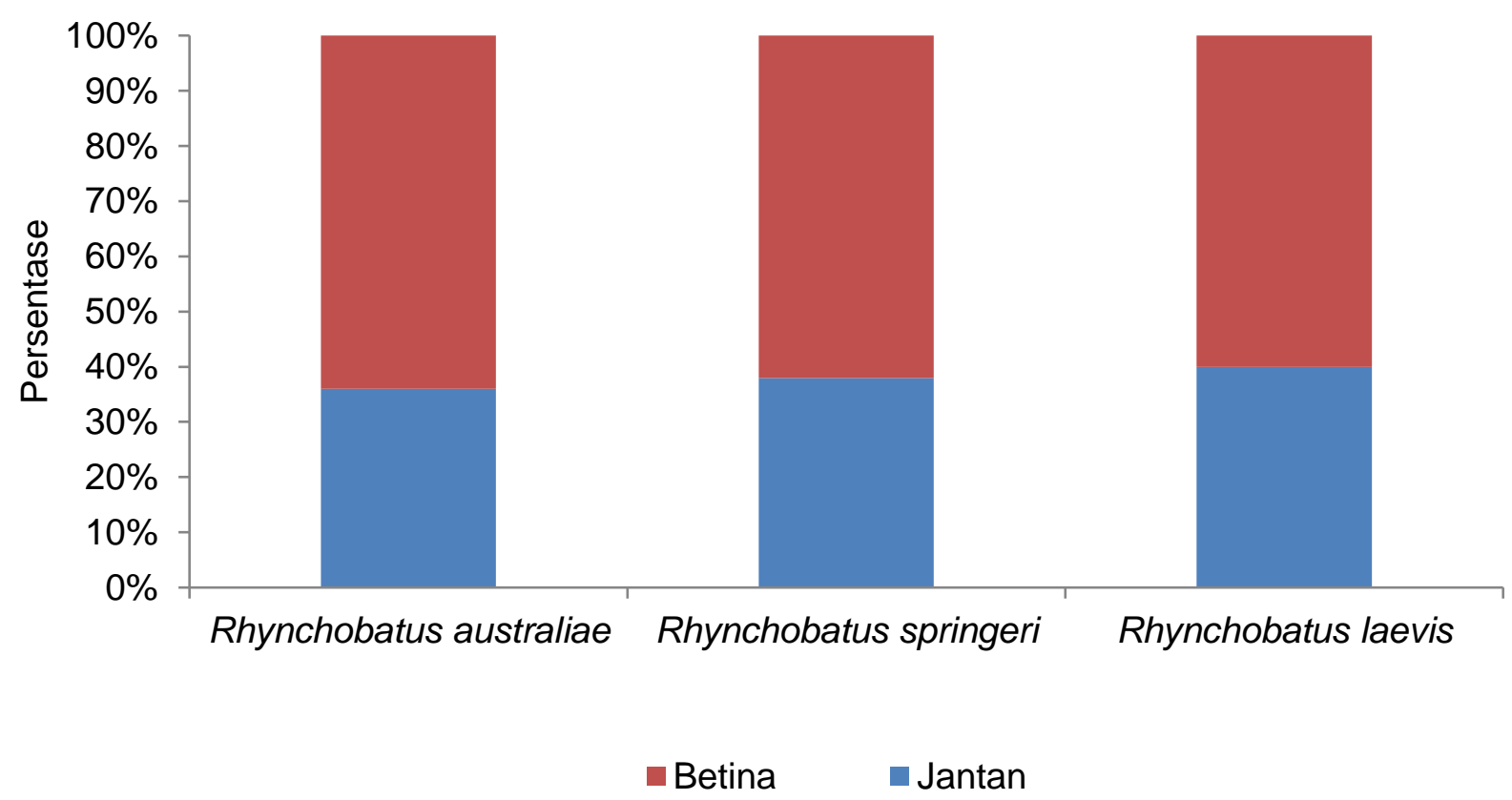

Gambar 8. Komposisi Rasio Kelamin Rhynchobatus spp. di PPP Tasik Agung

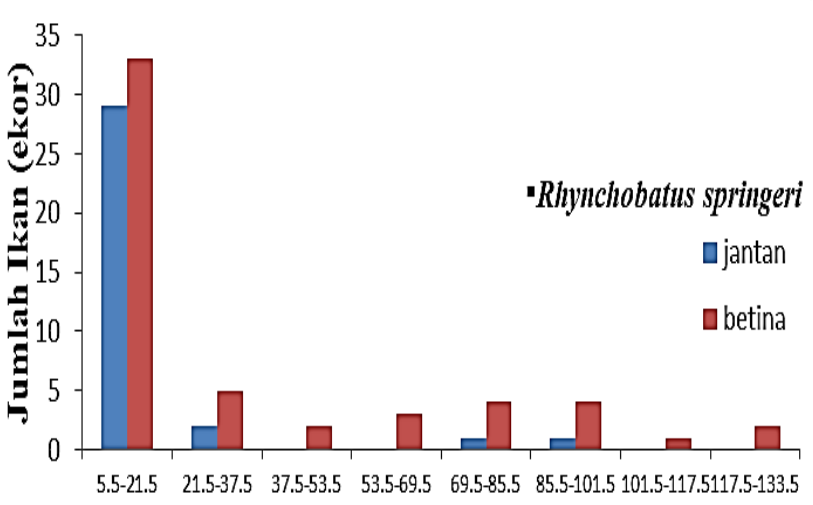

Kisaran Berat (kg)

Rhynchobatus springeri 


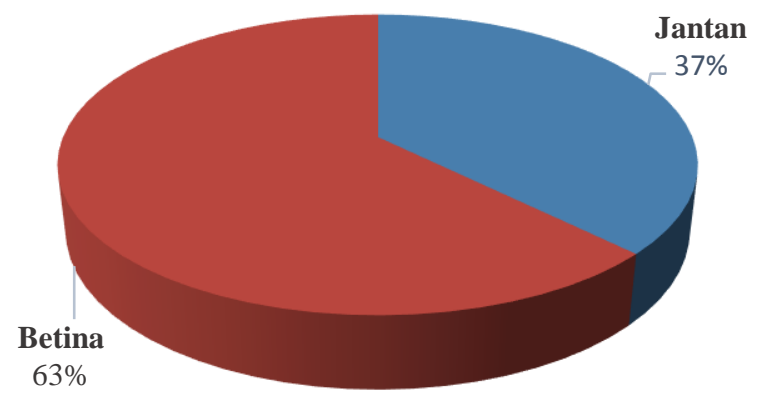

Gambar 7. Persentase Rasio Kelamin Rhynchobatus spp. di PPP Tasik Agung

\section{KESIMPULAN}

Kesimpulan yang diperoleh berdasarkan hasil penelitian ini adalah komposisi jenis pari kekeh (Rhynchobatus spp.) yang didaratkan di PPP Tasik Agung, Rembang terdiri dari 3 (tiga) spesies, yaitu Rhynchobatus australiae, Rhynchobatus springeri, dan Rhynchobatus laevis dengan komposisi secara berturut-turut sebanyak 49\%, 34\%, dan $17 \%$. Hubungan panjang total dan berat pari kekeh (Rhynchobatus spp.) menunjukkan bahwa pola pertumbuhan dari masingmasing jenis pari Rhynchobatus spp. bersifat alometrik negatif $(b<3)$, yaitu pertumbuhan panjang ikan lebih cepat dari pertumbuhan berat. Nisbah kelamin yang didapatkan dari pari kekeh Rhynchobatus australiae sebesar 1:1.78, pari Rhynchobatus springeri sebesar 1:1.64, dan pari Rhynchobatus laevis sebesar 1:1.50. Hasil uji Chi-square $\left(\mathrm{X}^{2}\right)$ dari masing-masing jenis pari Rhynchobatus spp. menunjukkan bahwa perbandingan individu jantan dan betina berbeda nyata atau dapat dikatakan tidak seimbang.

\section{DAFTAR PUSTAKA}

Abubakar, S., Boer, M., \& Sulistiono. 2015. Aspek Biologi Reproduksi Ikan Pari Total (Neotrygon kuhlii) di Perairan Selat Sunda. Jurnal Teknologi Perikanan dan Kelautan, 6(2): 129-138. DOI: 10.24319/jtpk.6.129-138

Alaydrus, I.S., Fitriana, N. \& Jamu, Y. 2014. Jenis dan Status Konservasi Ikan Hiu yang Tertangkap di Tempat Pelelangan Ikan (TPI) Labuan Bajo, Manggarai Barat, Flores. Jurnal Biologi, 7(2): 83-88. DOI: 10.15408/kauniyah.v7i2.2719

Azidha, L., Irwani, \& Munasik, 2021, Aspek Biologi Pari kekeh (Rhynchobatus sp.) (Rhinidae:Chondrichthyes) Studi Kasus di PPN Brondong, Lamongan. Journal of Marine Research, 10(1): 78-88. DOI: 10.14710/jmr.v10i1.28496

Ben-Hasan, A., Walters, C., Hordyk, A., Christensen, V., \& Al-Husaini, M. 2021. Alleviating Growth and Recruitment Overfishing through Simple Management Changes: Insights from an Overexploited Long-Lived Fish. Marine and Coastal Fisheries, 13(2): 87-98.

Compagno, L. \& Last P. 2010. A New Species of Wedgefish, Rhynchobatus palpebratus sp. nov (Rhynchobatoidei: Rhynchobatidae), from the Indo-West Pacific. CSIRO Marine and Atmospheric Research no 22, Hobart, 240 p.

Dent, F. \& Clarke, S. 2015. State of the global market for shark products. FAO Fisheries and Aquaculture Technical Paper no 590, Rome, $187 \mathrm{p}$.

Dharmadi \& Kasim, K., 2010, Keragaan Perikanan Cucut dan Pari di Laut Jawa, Jurnal Penelitian Perikanan Indonesia, 16(3): 205-216. DOI: http://dx.doi.org/10.15578/jppi.16.3.2010.205-216

Dharmadi, Wiadnyana, N.N., \& Nugroho, D. 2020. Pedoman Pendataan Perikanan Hiu dan Pari di Lokasi Pendaratan. Badan Riset dan Sumber Daya Manusia Kelautan dan Perikanan, Jakarta, $35 \mathrm{p}$.

Dinas Kelautan dan Perikanan Kabupaten Rembang. 2016. Data Produksi dan Nilai Produksi Ikan Laut Menurut Jenis Ikan di Kabupaten Rembang, 2014-2016. Kementerian Kelautan dan Perikanan Republik Indonesia, Jakarta. 
Dinas Kelautan dan Perikanan Kabupaten Rembang. 2018. Data Produksi dan Nilai Produksi Ikan Laut Menurut Jenis Ikan di Kabupaten Rembang, 2017-2018. Kementerian Kelautan dan Perikanan Republik Indonesia, Jakarta.

Direktorat Jenderal Perikanan Tangkap. 2016. Data Statistik Perikanan Tangkap Menurut Provinsi di Indonesia. Kementerian Kelautan dan Perikanan Republik Indonesia, Jakarta.

Direktorat Jenderal Perikanan Tangkap. 2017. Data Statistik Perikanan Tangkap Nasional di Indonesia. Kementerian Kelautan dan Perikanan Republik Indonesia, Jakarta.

Direktorat Jenderal Perikanan Tangkap. 2018. Data Statistik Perikanan Tangkap Menurut Provinsi di Indonesia. Kementerian Kelautan dan Perikanan Republik Indonesia, Jakarta.

Direktorat Konservasi dan Keanekaragaman Hayati Laut. 2019. Profil Perikanan Pari Liong Bun, Pari Kikir dan Hiu Mako di Indonesia. Kementerian Kelautan dan Perikanan Republik Indonesia, Jakarta, $38 \mathrm{p}$.

Effendi, H.P., Alkadrie, I.T., Dhewi, R.T. \& Ricky. 2018. Jejaring Pemanfaatan Hiu dan Pari di Balikpapan. Prosiding Simposium Nasional Hiu Pari Indonesia Ke-2. Kementerian Kelautan dan Perikanan Republik Indonesia, Jakarta, pp. 255-263.

Fahmi \& Dharmadi. 2013. Tinjauan Status Perikanan Hiu dan Upaya Konservasinya di Indonesia. Direktorat Konservasi Kawasan dan Jenis Ikan, Direktorat Jenderal Kelautan, Pesisir dan PulauPulau Kecil, Jakarta, 179 p.

Faizah, R. \& Chodrijah, U. 2020. Size distribution and population parameter of white-spotted wedgefish (Rhynchobatus Australiae Whitley, 1939) from the Eastern Indian Ocean, Indonesia. IOP Conference Series: Earth and Environmental Science, 584(1): 1-8. DOI: 10.1088/1755$1315 / 584 / 1 / 012034$

Ghozali, I. 2016. Aplikasi Analisis Multivariete Dengan Program IBM SPSS 23. Edisi 8. Semarang: Badan Penerbit Universitas Diponegoro.

Giles, J.L., Riginos, C., Naylor, G.J.P., Dharmadi, \& Ovenden, J.R. 2016. Genetic and phenotypic diversity in the wedgefish Rhynchobatus australiae, a threatened ray of high value in the shark fin trade. Marine Ecology Progress Series, 548: 165-180. DOI: 10.3354/meps 11617

Jabado, R.W. 2019. Wedgefishes and Giant Guitarfishes: A Guide to Species Identification. Wildlife Conservation Society, New York, $30 \mathrm{p}$.

Kusrini \& Aba. 2019. Struktur Anatomis Valvula Intestinalis Pari Gitar. Jurnal Florea, 6(1): 20-27. DOI: $10.25273 /$ florea.v6i1.4366

Kyne, P.M. 2019. Rhynchobatus springeri. The IUCN Red List of Threatened Species 2019: e.T60182A124448942. DOI: 10.2305/IUCN.UK.2019-2.RLTS.T60182A124448942.en

Kyne, P.M., Rigby, C.L., Dharmadi, \& Jabado, R.W. 2019. Rhynchobatus australiae. The IUCN Red List of Theatened Species 2019: e.T41853A68643043. DOI: 10.2305/IUCN.UK.2019-2.RLTS. T41853A68643043.en

Last, P.R., White, W.T., de Carvalho, M.R., Sertr, B., Stehmann, M.F.W. \& Naylor, G.J.P. 2016. Rays of the World. CSIRO Publishing, Victoria, $800 \mathrm{p}$.

Mutaqqin, E., Simeon, B.M., Ichsan, M., Dharmadi, Prasetyo, A.P., Booth, H., Yulianto, I. \& Friedman, K. 2018. The Scale, Value, and Importance of Non-Fin Shark and Ray Commodities in Indonesia. FAO, Rome, $66 \mathrm{p}$.

Oktaviyani, S., Kurniawan, W. \& Fahmi. 2020. Komposisi spesies dan distribusi ukuran hiu dan pari yang tertangkap di Selat Bali dan perairan sekitarnya serta kaitannya dengan pengelolaan perikanan. Jurnal Iktiologi Indonesia, 20(1): 23-46. DOI: 10.32491/jii.v20i1.509

Omar, S.B.A., Nur, M., Umar, M.T., Dahlan, M.A., \& Syarifuddin, K. 2015. Nisbah Kelamin dan Ukuran Pertama Kali Matang Gonad Ikan Endemik Pirik (Lagusia micracanthus Bleeker, 1860) di Sungai Pattunuang, Kabupaten Maros, dan Sungai Sanrego, Kabupaten Bone, Sulawesi Selatan. Semnaskan Universitas Gajah Mada, 73-84.

Rizal, M. \& Jaliadi. 2018. Komposisi dan Hubungan Panjang Berat Ikan Hasil Tangkapan Jaring Insang Dasar diperairan Aceh Barat Meulaboh. Jurnal Perikanan Terpadu, 1(2):1-11. DOI: 10.35308/jupiter.v1i2.803

Simeon, B.M., M. Ichsan, E. Muttaqin, S. Agustina, A.P. Prasetyo, Dharmadi, \& I. Yulianto. 2019. Laporan Teknis: Profil Perikanan Wedgefish di Indonesia, Studi Kasus di Nusa Tenggara Barat dan Aceh. Wildlife Conservation Society Indonesia, Bogor, 25 p. 
Suryatati, Budiman, S. \& Martidi, R.A. 2019. Efektivitas Program Pengembangan Perikanan Tangkap di Kelurahan Kampung Bugis oleh Dinas Pertanian, Pangan, dan Perikanan (DP3) Kota Tanjungpinang. Jurnal FisiPublik, 4(2): 150-158. DOI: 10.24903/fpb.v4i2.752

Triharyuni, S., Utama, A.A., Zulfia, N. \& Sulaiman, P.S. 2017. Komposisi, Sebaran Ukuran dan Hubungan Panjang-Berat Beberapa Jenis Ikan Petek (Leiognathidae) di Teluk Jakarta. Jurnal Bawal, 9(2): 75-83. DOI: 10.15578/bawal.9.2.2017.75-83

White, W.T., Last., P.R., Stevens, J.D., Yearsley, G.K., Fahmi \& Dharmadi. 2006. Economically Important Sharks and Rays of Indonesia (Hiu dan Pari yang Bernilai Ekonomis Penting di Indonesia). ACIAR Monograph Series; no. 124. Australian Centre for International Agricultural Research, Canberra, 329 p.

Yuwandana, D.P., Pranata, I.A.W., Agustina, S., Hartati, I.D., Muttaqin, E. \& Simeon, B.M. 2020a. Status Perikanan Pari Kekeh (Rhinidae) dan Pari Kikir (Glaucostegidae) di Perairan Utara Jawa. Rekam Nusantara Foundation, Bogor, $36 \mathrm{p}$.

Yuwandana, D.P., Agustina, S., Haqqi, M.B. \& Simeon, B.M., 2020b, Studi Awal Perikanan Pari Kekeh (Rhynchobatus sp.) dan Pari Kikir (Glaucostegus sp.) di Perairan Utara Jawa Tengah, Jurnal Akuatika Indonesia, 5(1):84-91. DOI: 10.24198/jaki.v5i1.25938

Zain, B.M., Mutalib, S.A.A. \& Aifat, N.R. 2018. Molecular Phylogenic Inference of White Spotted Guitarfish (Rhynchobatus australiae) Collected from Local Malaysian Fish Markets. Biodiversitas Journal of Biological Diversity, 19(4): 1382-1386. DOI: 10.13057/biodiv/d190426 